\title{
Die rol van die US se Departement Afrikaans en Nederlands in die ontwikkeling van die Afrikaanse leksikografie onder Nederlandse invloed: Verklarende standaardwoordeboeke
}

Gerda Odendaal, Departement Afrikaans en Nederlands, Universiteit Stellenbosch, Stellenbosch, Suid-Afrika (godendaal@sun.ac.za)

Opsomming: Hierdie artikel stel ondersoek in na die rol van die Universiteit Stellenbosch se Departement Afrikaans en Nederlands in die ontwikkeling van die Afrikaanse leksikografie deur hulle betrokkenheid by twee verklarende standaardwoordeboeke, te wete die Verklarende Handwoordeboek van die Afrikaanse Taal en Nasionale Woordeboek. Dit word gedoen teen die agtergrond van die invloed van Nederlands op die Afrikaanse leksikografie. Daar word veral gedui op die invloed van Nederlands op dié woordeboeke op sowel makro- as mikrostrukturele vlak. Daar word egter ook gedui op die geleidelike losbreek van die Nederlandse invloed en die bydrae van hierdie woordeboeke tot die ontwikkeling van die Afrikaanse leksikografie. Wanneer die ooreenstemmende uitgawes van dié woordeboeke met mekaar vergelyk word, word daar tot die gevolgtrekking gekom dat Nasionale Woordeboek minder Nederlandse invloed as die Verklarende Handwoordeboek van die Afrikaanse Taal blyk te toon. Die Verklarende Handwoordeboek van die Afrikaanse Taal het egter veral sedert die begin van die negentigerjare (nadat daar nie verdere uitgawes van Nasionale Woordeboek verskyn het nie) stadig maar seker begin om van Nederlandse invloed weg te breek, sodat die jongste uitgawe van dié woordeboek blyke gee van Afrikaans as 'n selfstandige taal wat nie langer op Nederlands hoef te steun nie.

Sleutelwoorde: UNIVERSITEIT STELLENBOSCH, DEPARTEMENT AFRIKAANS EN NEDERLANDS, AFRIKAANSE LEKSIKOGRAFIE, NEDERLANDSE INVLOED, NEERLANDISME, VERKLARENDE STANDAARDWOORDEBOEK, VERKLARENDE HANDWOORDEBOEK VAN DIE AFRIKAANSE TAAL, KERNWOORDEBOEK, NASIONALE WOORDEBOEK

\begin{abstract}
The Role of Stellenbosch University's Department of Afrikaans and Dutch in the Development of Afrikaans Lexicography: Development under Dutch Influence. This article investigates the role of Stellenbosch University's Department of Afrikaans and Dutch in the development of Afrikaans lexicography through their involvement in two standard descriptive dictionaries, the Verklarende Handwoordeboek van die Afrikaanse Taal en Nasionale Woordeboek. This is done against the background of the influence of Dutch on Afrikaans lexicography. The influence of Dutch on both the macro- and microstructures of these
\end{abstract}


dictionaries are investigated. A gradual movement away from Dutch influence and the contribution of these dictionaries to the development of Afrikaans lexicography are also indicated. When corresponding editions of the two dictionaries are compared, Nasionale Woordeboek seems to show less Dutch influence than Verklarende Handwoordeboek van die Afrikaanse Taal. However, since the beginning of the 1990s (after no new editions Nasionale Woordeboek appeared) Verklarende Handwoordeboek van die Afrikaanse Taal has slowly but surely started to free itself from Dutch influence. The result of this is that the most recent edition of the Verklarende Handwoordeboek van die Afrikaanse Taal gives evidence of Afrikaans as an independent language that no longer needs to rely on Dutch.

Keywords: STELLENBOSCH UNIVERSITY, DEPARTMENT OF AFRIKAANS AND DUTCH, AFRIKAANS LEXICOGRAPHY, DUTCH INFLUENCE, DUTCHISM, STANDARD DESCRIPTIVE DICTIONARY, VERKLARENDE HANDWOORDEBOEK VAN DIE AFRIKAANSE TAAL, KERNWOORDEBOEK, NASIONALE WOORDEBOEK

\section{Inleiding}

Die Universiteit Stellenbosch het in die twintigste eeu 'n belangrike bydrae gelewer tot die totstandkoming van die Afrikaanse leksikografie met die verskyning van die Nederlandse dosent, Nicolaas Mansvelt, se Proeve van een Kaapsch-Hollandsch Idioticon deurdat dit beskou is as die eerste selfstandige Afrikaanse woordeboek wat primêr op Afrikaanssprekendes gerig is en wat gedui het op die eiesoortigheid van Afrikaans as onafhanklike taal naas Nederlands (Gouws 1995: 48; Schoonheim 1998: 43; Gouws 2003: 79). 'n NederlandsAfrikaans-stryd tussen die voorstanders van Nederlands, wat onder leiding van die Stellenbosse dosent, W.J. Viljoen, gepoog het om 'n vereenvoudigde Nederlandse spelling deur die publikasie van verskeie woordeboeke in te voer, en die voorstanders van Afrikaans, wat hulle onder die leierskap van nóg ' $n$ Stellenbosser, J.J. Smith, beywer het om Afrikaans as onderrigmedium aan die Universiteit Stellenbosch erken te kry, het egter aan die begin van die twintigste eeu binne die Departement Afrikaans en Nederlands, maar ook in die breër Afrikaanse spraakgebied, posgevat. Dit het uiteindelik daartoe aanleiding gegee dat daar in ortografiese bereëling van Afrikaans teruggegryp is na Nederlands ten einde nie die voorstanders van Nederlands van die Afrikaanse ortografie te vervreem nie (vgl. Odendaal 2016). Die teruggryp na Nederlands sou uiteindelik ook neerslag vind in die leksikografiese vergestalting van Afrikaans.

Een van die woordeboeke waarin die Nederlands-Afrikaans-stryd neerslag gevind het, was die Woordeboek van die Afrikaanse Taal (vgl. Odendaal, om te verskyn). Dié woordeboek, wat aanvanklik veronderstel was om 'n verklarende standaardwoordeboek te wees, het mettertyd tot 'n omvattende verklarende woordeboek ontwikkel, aangesien die eerste hoofredakteur, J.J. Smith, die "versameling van die Afrikaanse woordeskat" as "'n volksaak" en "die voltooiing van die eerste min of meer volledige Afrikaanse woordeboek" as "'n volksgebeurtenis" beskou het (Snijman 1964: 11; 1975: 3). Die gevolg was dat daar 'n merkbare leemte in die Afrikaanse leksikografie ontstaan het, naamlik 'n 
gebrek aan 'n gesaghebbende verklarende standaardwoordeboek vir Afrikaans (Gouws en Ponelis 1992: 19). Alhoewel daar in 1936 'n deurbraak gemaak is met die verskyning van die Verklarende Afrikaanse Woordeboek, ${ }^{1}$ sou die belangrike bydraes tot die standaard verklarende leksikografie eers later hulle verskyning maak, onder andere Verklarende Handwoordeboek van die Afrikaanse Taal (1965) (Gouws en Ponelis 1992: 20). Waar verklarende standaardwoordeboeke gewoonlik 'n belangrike standaardiseringsrol vervul, kon hierdie woordeboeke weens hulle vertraagde verskyning nie vir hierdie doel in Afrikaans aangewend word nie (Gouws en Ponelis 1992: 19). Hierdie vertraging het egter volgens Gouws en Ponelis (1992: 19-20) die gevolg gehad dat dit die kwaliteit van die verklarende standaardwoordeboeke verhoog het wat uiteindelik verskyn het, aangesien hierdie woordeboeke kon put uit 'n toenemende bewustheid van die studie van die Afrikaanse taalkunde. Ten spyte hiervan het ook die standaard verklarende woordeboeke egter nie die Nederlandse invloed vrygespring nie.

In hierdie derde artikel $^{2}$ oor die rol van die Universiteit Stellenbosch (voortaan US), maar in die besonder sy Departement Afrikaans en Nederlands, in die ontwikkeling van die Afrikaanse leksikografie onder Nederlandse invloed, word daar veral op verklarende standaardwoordeboeke gefokus. Twee woordeboeke waarin verskeie dosente van die Departement Afrikaans en Nederlands deel gehad het, word in hierdie artikel onder die loep geneem, te wete die Verklarende Handwoordeboek van die Afrikaanse Taal en Nasionale Woordeboek. In die bespreking van hierdie woordeboeke word daar nie soseer op dié woordeboeke as gebruikersvriendelike naslaanbronne gefokus nie, maar eerder op die invloed van Nederlands op die woordeboeke, die wegbreek van Nederlandse invloed, asook hulle bydrae tot die Afrikaanse standaardleksikografie.

\section{Verklarende Handwoordeboek van die Afrikaanse Taal}

\section{$2.1 \quad$ HAT 1}

Teen die draai van die 1950's besluit die Raad van Beheer oor Die Afrikaanse Woordeboek om gelyklopend met die WAT ook aan 'n minder omslagtige verklarende woordeboek te werk (Odendal 2006: 281). In 1965 verskyn die eerste uitgawe van die Verklarende Handwoordeboek van die Afrikaanse Taal (voortaan HAT) onder redakteurskap van P.C. Schoonees (voormalige hoofredakteur van die WAT), C.J. Swanepoel (wat aan Stellenbosch gegradueer het) en S.J. du Toit (beide voormalige WAT-redaksielede), en C.M. Booysen (Schoonees, Swanepoel, Du Toit en Booysen 1965: 'n Woord vooraf). Hierdie woordeboek, wat "op dieselfde grondslag opgestel [is] as Die Woordeboek van die Afrikaanse Taal (WAT)", is teen 1067 bladsye "heelwat kleiner in omvang en beperkter van opset as WAT", aldus Schoonees et al. (loc.cit.). Alhoewel die US se Departement Afrikaans en Nederlands waarskynlik nie met hierdie uitgawe 'n direkte verbintenis met HAT gehad het nie, het die redaksie wel "professore van die Universiteit van 
Stellenbosch" in die voorwoord uitgesonder as medewerkers "wat hulp verleen het by die vasstelling van definisies" (Schoonees et al. loc.cit.). HAT se band met die WAT impliseer ook 'n redelike mate van samewerking tussen die HAT en die US (vgl. Odendaal, om te verskyn). Dié samewerking sou egter later meer prominent raak met R.H. Gouws se toetrede tot die redaksie van HAT (sien 2.4).

Die siening dat Nederlands "die onmisbare bron [is] waaruit Afrikaans moet put, oral waar voorlopig nie deur eie taalmiddels in die behoeftes kan voorsien word nie" wat aan die begin van die twintigste eeu in Afrikaanse taalgeledere posgevat het (Le Roux, Malherbe en Smith 1917: iv; vgl. Odendaal 2016: 265), het na die leksikografie oorgevloei. Ponelis (1992: 81) dui daarop dat die Afrikaanse leksikografie "ontwikkel [het] uit die vertaling van Nederlandse woordeboeke". Dat ook HAT 1 se Nederlandse onderrok plek-plek uithang, aldus Van Houwelingen en Carstens (1998: 3), blyk daaruit dat HAT "sowel mikrostruktureel as makrostruktureel sterk by Nederlands aanleun" (Van Houwelingen en Carstens 1998: 2). Vergelyk in hierdie verband die volgende lys Neerlandistiese ${ }^{3}$ lemmas of lemmas met 'n Neerlandistiese betekenis wat in HAT 1 opgeneem is met die frekwenter Afrikaanse vorme daarnaas: ${ }^{4}$

abonneer ("inteken", bv. op 'n koerant), abonnement ("intekening/subskripsie"), agternaam ("van"), benieu ("nuuskierig maak"), benieud ("nuuskierig"), bigotterie ("skynheiligheid"), bil ("boud"), bloesem ("bloeisel"), blootshoof(s) ("kaalkop"), blootsvoet(s) ("kaalvoet"), briewebesteller ("posbode/-man"), briewebus ("posbus"), felisiteer ("gelukwens"), felisitasie ("gelukwensing"), fiets (ww.) ("fietsry"), haag ("heining"), hals ("nek"), heg ("heining"), houthakker ("houtkapper"), internaat ("kosskool"), invasie ("inval"), invektief ("skel(d)woord"), invitasie ("uitnodiging"), jarig ("verjaar"), kameleon ("verkleurmannetjie"), kapper ("haarkapper"), kloset ("toilet"), kneding (handeling van "knie"), knee(d)baar ("kniebaar"), kus (s.nw./ww.) ("soen"), moedervlek ("geboortemerk/-vlek"), onbesuis ("roekeloos/onstuimig/wild), origineel ("oorspronklik"), pardon (tw.) ("ekskuus"), pinda ("grondboontjie"), serieus ("ernstig"), sielig ("droewig"), skavuit ("skelm/skurk"), spaarpot ("spaarbussie"), stopkontak ("muurprop/ kragpunt"), swyneboel ("vuil huishouding"), tarwe ("koring"), toonladder ("toonleer"), twyg ("dun takkie"), visite (s.nw.) ("besoek")

Behalwe kus (s.nw.), skavuit en tarwe, is al die bogenoemde lemmas ongeëtiketteerd opgeneem. Dit impliseer volgens Gouws $(1989: 147,201)$ dat hierdie lemmas (wat ongeëtiketteerd opgeneem is) korrekte en aanvaarde vorme in Standaardafrikaans is en skep sodoende die indruk by woordeboekgebruikers dat daar geen beperking op die gebruik van hierdie lemmas is nie. Kus, skavuit en tarwe is onderskeidelik met die stilistiese etikette w.g. (weinig gebruiklik) en verh. (verhewe) gemerk. Eersgenoemde, wat by skavuit en tarwe voorkom, dui daarop dat "'n woord wat wel dwarsoor die taalgebied bekend is" maar dat "die frekwensie om een of ander rede laag is", terwyl laasgenoemde, wat by kus voorkom, daarop dui dat die lemma bo die neutrale vlak van die standaardtaal lê (Odendal en Gouws 2005: xix, xv). Alhoewel temporele of herkomsetikette 
ontbreek wat die woordeboekgebruiker daarop wys dat dit hier eerder om verouderde of Neerlandistiese lemmas of betekenisse gaan, word die gebruiker wel daarop bedag gemaak dat hierdie lemmas afwyk van die standaardtaal (Gouws 1989: 147).

Behalwe Neerlandistiese lemmas, is daar ook Neerlandistiese betekenisonderskeidings in HAT 1 opgeneem. Vergelyk in hierdie verband die volgende woordeboekartikels in HAT 1:

bloot, b.nw. en bw. 1. Kaal, naak, onbedek: Met blote hoof, voete. 2. Sonder bedekking: Onder die blote hemel. Met die blote swaard, uit die skede getrek. Met die blote oog, sonder verkyker. 3. Sonder meer, eenvoudig: ' $n$ Blote gissing.

gi·raf', (-s, -fe; -fie). 1. Groot, geelbruin Afrikaanse dier met donkerbruin, onreëlmatige vlekke, baie lang nek en bene en gesplete kloue; kameelperd. 2. Giraf. Naam van 'n sterrebeeld; Camelopardalis.

ste'ker, (-s; -tjie). 1. Iemand wat steek. 2. Voorwerp, werktuig waarmee gesteek, wat ingesteek [kan] word, o.a. 'n luns, 'n elektriese (in)steekkontak e.d.

In die eerste voorbeeld is "kaal" as eerste betekenisonderskeiding by bloot sonder 'n leksikografie etiket opgeneem om daarop te dui dat dit hier om 'n Neerlandistiese betekenisonderskeiding gaan (vgl. Van Houwelingen en Carstens 1998: 7). Die indruk word geskep dat dit sowel die gebruiklikste as frekwentste betekenisonderskeiding in Afrikaans is; iets wat deur Van Houwelingen en Carstens (loc.cit.) se studie weerlê is. Alhoewel die gebruikliker, Standaardafrikaanse kameelperd as sinoniem by die eerste betekenisonderskeiding van giraf aangebied word, word die lemma giraf volledig bewerk terwyl HAT 1 by die lemma kameelperd slegs die sinoniemdefinisie "giraf" aanbied. Die indruk wat hierdeur by die gebruiker geskep word, is dat giraf die gebruikliker, Standaardafrikaanse vorm in Afrikaans is, terwyl dit (of eerder die gebruikliker spelvariant giraffe) Standaardnederlands verteenwoordig (De Boer 2015; Den Boon en Hendrickx 2015). Die tweede betekenisonderskeiding wat by steker aangebied word, stem eerder ooreen met die Afrikaanse kragprop. Hierdie inskrywing skep weer die indruk dat die gebruiker hier met 'n gebruiklike betekenisonderskeiding in Afrikaans te make het deurdat daar geen leksikografiese etikette aangebring is nie. Lemmas soos braaf, eventueel en fok is monosemies hanteer met slegs die Neerlandistiese betekenis (vgl. Carstens 1995a: 152), sonder die inagneming van die addisionele betekenisonderskeidings of alternatiewe betekenisse wat in Afrikaans ontwikkel het, naamlik "dapper", "uiteindelik" en die vulgêre betekenis van fok onderskeidelik:

braaf, b.nw. en bw. Gaaf, goed, deugsaam: Sy brawe ouers. ' $n$ Brawe Hendrik, Maria, seun, dogter wat [kastig] baie voorbeeldig is. 
e'ven·tu·eel', b.nw. en bw. Moontlik, gebeurlik: Eventuele klagtes kan by my ingedien word.

fok, ww. (gefok). Minder gewoon vir teel.

Carstens (1995a: 150) dui in haar bespreking van HAT 3 daarop dat daar ook "in die definisies van talle leksikale en subleksikale lemmas argaiese (dikwels Nederlandse) [...] woorde behou" is. Vergelyk in hierdie verband die volgende woordeboekartikels in HAT 1:

eer'lik, b.nw. en bw. [...] 2. Wat die waarheid spreek, wat die feite nie verdraai nie; opreg, betroubaar [...].

kleur'be·leid. Beleid ten opsigte van mense van 'n ander huidskleur.

stra'le·krans, stra'le·kroon. Krans, kring van lig om die hoof van goddelike, hemelse persone, op 'n skildery bv.; halo; oureool [...].

Die woorde spreek, huidskleur en hoof wat in bogenoemde definiense gebruik is, kon eerder met hulle frekwenter, Standaardafrikaanse ekwivalente praat, velkleur en kop vervang word.

Van Houwelingen en Carstens (1998: 10) dui verder daarop dat baie van die koteksinligting wat in HAT 3 aangetref word direkte vertalings van koteksinligting uit die Van Dale Groot Woordenboek der Nederlandse Taal (1982) blyk te wees. Dieselfde geld HAT 1 . Vergelyk in hierdie verband die poëme by sielig, skaats (s.nw.) en spaarpot in HAT 1 met die poëme by zielig, schaats (s.nw.) en spaarpot in die Van Dale Groot Woordenboek der Nederlandse Taal (1961) (Kruyskamp 1961; vgl. Van Houwelingen en Carstens 1998: 10):

\begin{tabular}{|l|l|l|l|}
\hline \multicolumn{2}{|c|}{ HAT 1 (1965) } & \multicolumn{2}{c|}{ Van Dale 8 (1961) } \\
\hline Lemma & Poëem & Lemma & Poëem \\
\hline sielig & Daar sielig uitsien. & zielig & Er zielig uitzien. \\
\hline skaats & Die skaatse aanbind. & schaats & De schaatsen aanbinden. \\
\hline spaarpot & Sy het 'n vet spaarpot. & spaarpot & Zij heeft een vette spaarpot. \\
\hline
\end{tabular}

Laastens bevat HAT 1 ook Neerlandistiese kollokasies en uitdrukkings. Vergelyk in hierdie verband die volgende inskrywings by die lemmas begaan en insien (vgl. Ponelis 1992: 81; Luther 2010: 677):

be·gaan'1, ww. (-). 1. Gaan, loop op: 'n Steil pad begaan. Die begane grond, deel van gebou gelyk met die grond. [...]

in'sien. I ww. (ingesien). [...] 4. Beoordeel, waarneem: Hy sien alles so duister in. $[\ldots]$

Die kollokasie begane grond wat by die eerste betekenisonderskeiding van begaan aangebied word, is eerder ' $\mathrm{n}$ Standaardnederlandse uitdrukking (Neder- 
landse Taalunie 2015; De Boer 2015; Den Boon en Hendrickx 2015) wat in Afrikaans vervang kan word met grondverdieping of grondvlak. Die voorbeeldmateriaal wat by die vierde betekenisonderskeiding van insien aangebied word, is in werklikheid 'n Nederlandse uitdrukking wat beteken "om die ergste te verwag" (Den Boon en Hendrickx 2015). In bogenoemde woordeboekartikels is daar egter geen aanduiding deur byvoorbeeld 'n leksikografiese etiket dat dit hier om Neerlandistiese betekenisonderskeidings gaan nie.

\subsection{HAT 2}

In 1971 word F.F. Odendal, ook 'n voormalige redaksielid van die WAT en 'n Stellenbosch-alumnus, tóé verbonde aan die Randse Afrikaanse Universiteit, genader om die hoofredakteurskap van HAT oor te neem. Nadat Odendal die woordeboek, wat reeds deur die vorige redakteurs hersien en uitgebrei is, verder hersien, aangepas en uitgebrei het tot sowat 1378 bladsye, verskyn die tweede uitgawe agt jaar later in 1979. Met die hersiening van hierdie uitgawe is daar veral gefokus op die korreksie van foute en die verfyning van definiense in bestaande woordeboekartikels, asook die byvoeging van lemmas "wat [...] algemeen in gebruik is" en die toevoeging van koteksinligting. Hiervoor is daar tot 'n mate geput uit die sesde uitgawe van die WAT (kla-kol). (Odendal 1979: Voorwoord by die tweede uitgawe; 2006: 283)

Volgens Odendal (2006: 283) is daar in hierdie uitgawe "argaïese woorde (en betekenisse) geskrap, veral ook woorde en betekenisse wat eerder Nederlands as Afrikaans was" (Odendal loc.cit.). Wanneer die lemmalys in 2.1 in ag geneem word, blyk dit egter dat daar in hierdie opsig in werklikheid nie veel sedert die vorige uitgawe verander het nie. Slegs een van die lemmas in hierdie lys is geskrap, naamlik pinda, terwyl daar ook weer ander Neerlandistiese lemmas toegevoeg is, soos belendend ("aangrensend") en stekker ("kragprop") (vgl. Ponelis 1992: 81; Van Houwelingen en Carstens 1998: 5). Daar is wel 'n aantal leksikografiese etikette bygevoeg wat die woordeboekgebruiker daarop bedag maak dat hierdie lemmas afwyk van Standaardafrikaans (Odendal 2006: 285; vgl. Gouws 1989: 201). By bil is die temporele etiket veroud. (verouderd) aangebring om daarop te dui dat die lemma "nog (dikwels) raakgeloop word maar tog in 'n mate in onbruik geraak het" (Odendal en Gouws 2005: xix). Haag en internaat is met die stilistiese etiket $w . g$. (weinig gebruiklik) gemerk en twyg met digt. (digterlik), wat daarop dui dat, alhoewel die lemma nie vreemd aandoen nie, dit meer algemeen voorkom in die werk van skrywers as in gewone spreektaal (Odendal en Gouws 2005: xvi). Saam met die stilistiese etiket nie alg. (nie algemeen), word die herkomsetiket F. (Frans) by die lemma visite aangetref. Eersgenoemde dui daarop dat die lemma 'n beperkte gebruik geniet (Odendal en Gouws 2005: xviii), waarskynlik aangesien daar 'n gebruikliker Afrikaanse ekwivalent bestaan ("besoek"). Laastens is die etiket onpers. (onpersoonlik) by die lemma benieu aangebring. Buiten die feit dat die afkorting onpers. in HAT 2 self opgeneem is, word daar nie in enige voortekste aangedui 
wat met hierdie etiket bedoel word nie; ook nie in latere uitgawes nie.

Die Neerlandistiese betekenisonderskeidings by bloot, steker, braaf en eventueel is behou sonder dat die Afrikaanse betekenisse of betekenisonderskeidings bygevoeg is of as die gebruiklikste betekenisse aangedui is. By braaf is daar selfs verder gegaan deurdat die volgende opmerking aan die woordeboekartikel toegevoeg is:

Braaf het nie in Afr. die betekenis van "dapper" nie.

Hierdeur is die Neerlandistiese betekenis nog meer eksplisiet gemaak. Ook by fok is die Afrikaanse betekenis steeds nie toegevoeg nie, maar die lemma met sy Neerlandistiese betekenis is wel uit die woordeboek verwyder.

Dat Odendal (2006: 283) inderdaad "omsigtig te werk gegaan" het "veral met die oog op ouer taalgebruikers", blyk daaruit dat daar nog baie Neerlandistiese lemmas en betekenisonderskeidings in HAT 2 behou is.

\section{$2.3 \quad$ HAT 3}

Die "nuwe, verbeterde, uitgebreide en omgewerkte derde uitgawe" verskyn in 1994 - vyftien jaar ná die verskyning van HAT 2. Dat daar in hierdie vyftien jaar daaraan gewerk is om 'n woordeboek daar te stel wat op leksikografiese beginsels geskoei is, blyk reeds uit die "Voorwoord by die derde uitgawe". HAT 3 verteenwoordig volgens Beyer (2005: 4) "'n waterskeiding in gebruiksleiding in dié woordeboek", aangesien Odendal (1994: Voorwoord by die derde uitgawe) in die voorwoord "verantwoording doen aan sy gebruikers met betrekking tot sy doelstellings en [...] van sy werkswyse". Sodoende word HAT 3 "die eerste Afrikaanse woordeboek wat geprobeer het om 'n behoorlike uiteensetting te gee van sy werkwyse en die teoretiese beginsels waarop dit berus", aldus Odendal (2006: 286).

So word HAT vir die eerste keer pertinent as 'n standaardwoordeboek onderskei deurdat dit "nie 'n volledige beeld en behandeling van die Afrikaanse woordeskat kan of wil gee nie", maar "die algemeenste woorde van Standaardafrikaans" opneem (Odendal 1994: Voorwoord by die derde uitgawe). Die onderskeiding as standaardwoordeboek word ook bevestig deur die feit dat Odendal (loc.cit.) hom in die samestelling van HAT 3 gehou het aan die "rigsnoer van wat [...] as Standaardafrikaans beskou word", naamlik die Afrikaanse woordelys en spelreëls soos saamgestel deur "die hoogste gesag oor Afrikaans", die Taalkommissie van die Suid-Afrikaanse Akademie vir Wetenskap en Kuns. Gegewe die eksplisiete verbintenis met Standaardafrikaans in HAT 3, sou 'n mens verwag dat talle van die Neerlandismes wat nog aanwesig was in vorige uitgawes in hierdie uitgawe geskrap sou word. Dat Odendal (loc.cit.) "aan die konserwatiewe kant [ge]sondig" het, blyk daaruit dat slegs toonladder geskrap is uit die lys Neerlandistiese lemmas wat in 2.1 aangebied is. 
As rede voer Odendal (loc.cit.) aan dat hierdie lemmas na sy mening "nog in genoeg geskrifte of in die taal van ouer sprekers voorkom".

Ten spyte daarvan dat daar nog heelwat Neerlandistiese lemmas in HAT 3 voorkom, word die gebruik van hierdie lemmas beperk deurdat daar in hierdie uitgawe meer aandag geskenk is aan die toevoeging van leksikografiese etikette (Odendal loc.cit.; 2006: 285; vgl. Gouws 1989: 201). Die volgende stilistiese etikette is byvoorbeeld toegevoeg waar daar voorheen geen etikette was nie:

\begin{tabular}{|l|c|}
\hline Lemma & Leksikografiese etiket(te) \\
\hline abonneer/abonnement & w.g. \\
\hline belendend & w.g. \\
\hline benieud & w.g. \\
\hline bloot & ietwat deftig \\
\hline blootshoof(s) & deftig \\
\hline felisiteer/felisitasie & deftig \\
\hline hals & deftig \\
\hline heg & deftig \\
\hline houthakker & verouderend \\
\hline invasie & w.g., deftig \\
\hline invektief & w.g., deftig \\
\hline invitasie & deftig \\
\hline kameleon & w.g. \\
\hline kloset & veroud. \\
\hline moedervlek & veroud. \\
\hline origineel & w.g. \\
\hline pardon & w.g., deftig \\
\hline serieus & deftig \\
\hline sielig & deftig \\
\hline
\end{tabular}

Ander lemmas se leksikografiese etikette is uitgebrei, byvoorbeeld benieu is nou ook as w.g. (weinig gebruiklik) geëtiketteer, internaat as deftig, twyg as veroud. (verouderd) en visite as deftig. Daarbenewens word haag nou eerder as verouderd as weinig gebruiklik beskou en kus as deftig en digterlik. Hoewel die Neerlandistiese betekenisonderskeiding by steker nog voorkom, is daar in HAT 3 nou 'n stilistiese etiket by die Neerlandistiese betekenisonderskeiding byvoeg om daarop te dui dat dit "nie as neutraal beskou kan word en dus vrylik gebruik kan word nie" (Odendal 1994: Voorwoord by die derde uitgawe). Alhoewel Odendal (loc.cit.) in die "Voorwoord" dui op die probleme wat hy ondervind het met die aanbring van die leksikografiese etikette en beken dat daar gevalle kon "deurglip" waarby 'n mens etikette sou verwag, het Odendal deur die ruimer insluiting van leksikografiese etikette in HAT 3 aan "een van die woordeboek se sentrale opdragte van taalbeskrywing" voldoen, aldus Ludwig (1982, in Gouws 1989: 32). Leksikografiese etikette word egter nie net effektief in die 
sentrale teks toegepas nie, maar ook deeglik in die "Voorwoord" verantwoord, aldus Beyer (2005: 31). Dit verteenwoordig volgens Beyer (2005: 6) ook goeie leksikografiese praktyk dat die funksie en aanwending van die leksikografiese etikette in 'n voorteks getiteld "Gebruiklikste etikette en afkortings" uiteengesit is.

Voorts is die koteksinligting by die frekwenter derde betekenisonderskeiding van bloot uitgebrei:

bloot, b.nw. en bw. 1. (ietwat deftig) Kaal, naak, onbedek: Met blote hoof, voete. 2. Sonder bedekking: Onder die blote hemel. Met die blote swaard, uit die skede getrek. Met die blote oog, sonder verkyker. Vgl. ONTBLOOT. 3. Sonder meer, eenvoudig: ' $n$ Blote gissing. Sommer uit blote nuuskierigheid vra. Dit was blote toeval dat ek hom gesien het. Die blote feit dat jy so ' $n$ wilde bewering maak, bewys jou onwetenskaplikheid, bevooroordeeldheid.

Braaf en eventueel wat in die vorige uitgawes nog monosemies en met Neerlandistiese betekenisse hanteer is, is in HAT 3 uitgebrei met die toevoeging van Afrikaanse betekenisonderskeidings. Braaf kan nou ook "dapper" beteken, terwyl eventueel nou "uiteindelik" kan beteken. By die lemma insien (ww.), waar die Nederlandse uitdrukking "Hy sien alles so duister in" as voorbeeldmateriaal aangebied is, word die betekenisonderskeiding waarin hierdie uitdrukking voorkom nou as weinig gebruiklik geëtiketteer. Gebruikers word in hierdie uitgawe selfs direk "gewaarsku" teen die gebruik van Neerlandismes deurdat die volgende opmerking by die lemma aanry aangebring is:

OPM.: Aanry in die bet. "met iemand bots terwyl jy ry", "in 'n ongeluk betrokke wees" is 'n Neerlandisme wat vermy moet word.

In die vorige uitgawes is hierdie Neerlandistiese betekenisonderskeiding ongeëtiketteer (m.a.w. as Standaardafrikaans) aangebied.

Die voorbeeldmateriaal is ook enigermate "verafrikaans" deurdat Odendal sitate uit die Afrikaanse literatuur toegevoeg het waar voorheen slegs of geen poëme aangebring was (Odendal 2006: 286). Enkele voorbeelde hiervan is sitate uit die werk van D.J. Opperman (vgl. blikkies), Antjie Krog (vgl. duf, betekenisonderskeiding 1), Wilma Stockenström (vgl. fluks, betekenisonderskeiding 2), M.E.R. (vgl. gemeen, betekenisonderskeiding 3c), C.L. Leipoldt (vgl. graf, betekenisonderskeiding 1a), Boerneef (vgl. hiernatoe), en Elisabeth Eybers (vgl. inkrimp, betekenisonderskeiding $1 \mathrm{~b}$ ) wat in HAT 3 aangebring is.

Die groter mate van leksikografiese verantwoordbaarheid waarna daar in hierdie uitgawe gestreef is, blyk ook uit Odendal (1994: Voorwoord by die derde uitgawe) se benadering ten opsigte van deskriptiwiteit teenoor preskriptiwiteit in HAT 3. Odendal (loc.cit.) se besluit om in HAT 3 "onomwonde" aan te dui "as 'n sekere woord, vorm of betekenisonderskeiding nie aanvaarbaar is nie", strook met die meer preskriptiewe funksie van standaard verklarende woordeboeke (vgl. Gouws 1989: 70). Tog dui Carstens (1995a: 164) daarop dat daar tot 'n groot mate "gebreek [is] met die elitistiese preskriptiwiteit en 
ongesonde purisme wat Afrikaans so lank gemuilband het". Behalwe die opname van enkele woorde uit die omgangstaal soos bodder, laitie, skedonk, skiewie, stres, tjopper en woema, is "nie alles wat maar na Engels lyk of ruik, [...] geban nie", byvoorbeeld blues, Country, cowboy, establishment, folk, jop, shandy, soul, steak, tjop en walkman (Odendal loc.cit.; Carstens 1995a: 155).

\section{$2.4 \quad$ HAT 4}

Kort ná die verskyning van HAT 3 in 1994 sluit R.H. Gouws, ook 'n Stellenbosch-alumnus en dosent aan die Departement Afrikaans en Nederlands, hom by Odendal as redakteur van HAT aan (Odendal en Gouws 2000: v; Odendal 2006: 287). Gouws, wat sedert 1980 taalkunde en leksikografie aan die US se Departement Afrikaans en Nederlands doseer, was teen hierdie tyd reeds 'n gerekende leksikograaf op sowel plaaslike as internasionale vlak (Odendal en Gouws loc.cit.; Odendal loc.cit.; Botha, in Botha, Mavoungou en Nkomo 2013: ix). As praktiese leksikograaf was hy betrokke by verskeie woordeboekprojekte, en as teoretiese leksikograaf het hy die leksikografie as vakgebied in Suid-Afrika gevestig en was hy ook reeds aktief betrokke op die internasionale leksikografiese verhoog (Odendal en Gouws loc.cit.; Odendal loc.cit.; Botha loc.cit.; Swanepoel, in Botha, Mavoungou en Nkomo 2013: Agterblad). Volgens Carstens (1994: 252-253) het die Afrikaanse metaleksikografie 'n hoogtepunt bereik met die publikasie van Gouws se leksikografiese handleiding Leksikografie in 1989 deurdat dit aanleiding gegee het tot ' $n$ toename in die publikasie van leksikografiese artikels. Nog 'n dosent van die US se Departement Afrikaans en Nederlands wie se naam genoem word as iemand wat gehelp het om leemtes in HAT 4 uit te wys en aanbevelings vir verbeterings gedoen het, is A.E. Feinauer (Odendal en Gouws loc.cit.).

Een van Gouws se eerste take was om 'n elektroniese weergawe van $H A T$ op CD-ROM beskikbaar te stel. Die ELHAT, soos die elektroniese HAT genoem is, is in 1998 bekendgestel en het "met 'n besliste toegevoegde waarde die terrein van die elektroniese leksikografie betree". (Odendal en Gouws loc.cit.; Odendal loc.cit.) In 2000 verskyn die vierde uitgawe van HAT. Alhoewel hierdie uitgawe nie uitvoerig hersien is nie, is daar wel 'n aantal argaïese lemmas uit die woordeboek verwyder (Odendal en Gouws loc.cit.; Odendal 2006: 288). Dit sluit in abonneer/abonnement, belendend, bigotterie en haag. Waar verouderde, Neerlandistiese woorde nie geskrap is nie, is leksikografiese etikette weereens toegevoeg of aangepas ten einde op die beperkte gebruik van hierdie lemmas te dui. So kry agternaam en bloesem wat voorheen ongeëtiketteerd was nou onderskeidelik die stilistiese etikette w.g. (weinig gebruiklik) en deftig, terwyl houthakker, wat in HAT 3 nog as verouderend geëtiketteer is, nou verouderd is. 'n Interessante geval is benieu en benieud wat, in stede van weinig gebruiklik (soos in HAT 3), nou verander is na deftig. Die Neerlandistiese betekenisonderskeiding by braaf ("Gaaf, goed, deugsaam") is in hierdie uitgawe as verouderend geëtiketteer, terwyl fok weer opgeneem is, maar hierdie keer met sy Afrikaanse (vulgêre) 
betekenis. Die lemma kleurbeleid (en daarmee saam sy Neerlandistiese definiens) is ook geskrap, terwyl die poëem "Die begane grond" nou as weinig gebruiklik geëtiketteer is.

Dat daar, soos in die vorige uitgawe, enigsins wegbeweeg is van 'n streng preskriptiewe benadering, blyk volgens Beyer (2005: 3) daaruit dat daar in die makrostruktuur nie slegs standaardtaalitems opgeneem is nie, maar ook "woorde wat algemeen in die spreektaal voorkom" (Odendal en Gouws loc.cit.). Dit sluit direkte en verafrikaanste leenwoorde uit Engels in, byvoorbeeld cool, sorry, oukei en orraait (Odendal en Gouws loc.cit.). Dat hierdie lemmas egter met die etikette geselst. (geselstaal) en E. (Engels) gemerk is, dui daarop dat dit veral tot die informele register beperk is, hoewel dit as "nuttig, algemeen, gebruiklik" beskou word (Odendal en Gouws 2000: xvii-xviii). HAT 4 vervul dus "'n deskriptiewe funksie deurdat die leksikon van Standaardafrikaans beskryf word" (Beyer loc.cit.; My beklemtoning - G.O.), maar ook deur erkenning te gee aan die omgangstaal "van 'n groot groep sprekers van die standaardvariëteit van Afrikaans" (Odendal en Gouws 2000: v). Dié woordeboek is egter steeds preskriptief deurdat daar duidelike uitsprake gemaak word oor die standaardheid, al dan nie, van sekere lemmas (Beyer loc.cit.). Tog dui die opname van spreektaalvorme enigermate op 'n erkenning van Afrikaans as ' $n$ selfstandige, lewenskragtige taal wat nie langer op Nederlands hoef te steun nie (sien 2.1), maar wat nou "deur eie taalmiddels" in sy sprekers se behoeftes kan voorsien.

Soos in HAT 3 is die aantal sitate in woordeboekartikels uitgebrei ten einde "'n beeld van die werklike gebruik van Afrikaans te gee". In hierdie uitgawe is daar veral gefokus op sitate uit ligte literatuur en literatuur deur jonger skrywers, om sodoende verder erkenning te gee aan die lewenskragtigheid van Afrikaans. (Odendal en Gouws loc.cit.)

\section{$2.5 \quad H A T 5$}

In 2005, veertig jaar ná die verskyning van die eerste $H A T$, word die vyfde uitgawe gepubliseer (Odendal 2006: 280). Alhoewel HAT 5, soos die vorige uitgawe, nie grondig hersien is nie, is daar volgens Botha (2005: 15) tog "heelwat waarde toegevoeg tot die inhoud van die vierde uitgawe". In die redakteurs se volgehoue poging om die makrostruktuur van HAT so verteenwoordigend moontlik te maak van die volle Afrikaanse spraakgemeenskap en daardeur uiting te gee aan die selfstandigheid en lewenskragtigheid van Afrikaans (vgl. 2.4), is daar weer 'n aantal (veral Engelse) leenwoorde en woorde uit ander variëteite as Standaardafrikaans opgeneem (Odendal en Gouws 2005: vii; Odendal 2006: 289). Voorbeelde hiervan is die lemmas baai (tw.), baasterd/bastard, babasit, babasitter, babawagter, gapjaar, gazebo, gender, globalisasie/globalisering, gumbootdans, happening, jackpot, mechanic, samie, SMS en vaalseun wat opgeneem is (vgl. Botha loc.cit.). Daar is eweneens erkenning gegee aan die invloed van ander inheemse Afrikatale op Afrikaans deur die insluiting van 'n aantal herkomsetikette wat 
Afrikaans se band met dié tale illustreer, byvoorbeeld So. (Sotho), Xh. (Xhosa) en Z. (Zulu) wat onderskeidelik by die lemmas kgotla, Masakhane en kleza/klêza aangebring is.

Die meer deskriptiewe benadering tot opname wat in HAT 5 gevolg is, is volgens Botha (loc.cit.) waarskynlik te danke aan die feit dat die keuse van lemmas in hierdie uitgawe vir die eerste keer gebaseer is "op ' $n$ verteenwoordigende, uitgebreide en gebalanseerde elektroniese korpus" (Odendal 2006: 288). Die gebruikmaking van 'n Afrikaanse korpus is eweneens tekenend van die ontwikkeling van Afrikaans tot selfstandige taal - daar hoef nie meer op 'n gevestigde standaardtaal (soos Nederlands) en sy leksikografiese produkte gesteun te word om Afrikaans op leksikografiese gebied uit te brei nie (sien 2.1), aangesien Afrikaans oor voldoende middele beskik om self ' $n$ verteenwoordigende standaard daar te stel.

Vervolgens is daar in hierdie uitgawe weer Neerlandistiese lemmas soos skavuit en stekker verwyder, terwyl blootsvoet(s), onbesuis en spaarpot onderskeidelik met die stilistiese etikette deftig, verouderend en deftig, en w.g. (weinig gebruiklik) gemerk is. By eventueel word die Afrikaanse betekenisonderskeiding ("uiteindelik") soos oorgeneem uit Engels, nou eerste aangebied, terwyl die Neerlandistiese betekenisonderskeiding ("moontlik, gebeurlik") nou as Neerlandisties en weinig gebruiklik geëtiketteer is. By stralekrans/stralekroon is die woord hoof wat sedert die eerste uitgawe in die definiens voorkom uiteindelik met kop vervang. In HAT 5 word daar selfs 'n stappie verder gegaan as in vorige uitgawes, deurdat gebruikers by sommige lemmas deur middel van leksikografiese etikette en in teksbokse gewaarsku word teen die gebruik van Neerlandismes. Vergelyk in hierdie verband die leksikografiese etiket Neerlandisties by eventueel soos uitgewys hierbo en by die lemmas geluiddemper, geluiddig en geluidsgrens, die etiket Neerlandisme by die lemma dagorde, die etiket $\mathrm{Ndl}$. (Nederlands) by die lemmas geneeswyse en weder-, asook die etiket Meer $\mathrm{Ndl}$. by die lemma geneë..$^{5}$ Die opmerking wat gebruikers sedert HAT 3 teen die Neerlandistiese betekenisonderskeiding van die lemma aanry waarsku, is nou selfs meer prominent gemaak deurdat dit in 'n teksboks geplaas is:

Aanry in die bet. "met iemand bots terwyl jy ry", "in 'n ongeluk betrokke wees" is 'n Neerlandisme wat vermy moet word.

Gebruikers word in hierdie uitgawe as 't ware weer aktief "gewaarsku" teen die gebruik van Neerlandismes, wat enigermate daarop dui dat Afrikaans 'n onafhanklike taal naas Nederlands is wat eie ontwikkeling ten opsigte van sy leksikon ondergaan het en nie meer onder die invloed van Nederlands staan nie.

Ná die verskyning van HAT 5 tree Odendal na meer as dertig jaar uit as redakteur van HAT (Odendal 2006: 289). Gouws bly egter betrokke as konsultant en nasienredakteur. Twee jaar later stel die uitgewer vir die eerste keer in HAT se geskiedenis ' $n$ voltydse redakteur, die leksikograaf J. Luther, aan. (Luther, Pheiffer en Gouws 2015: vii) In 2009 verskyn die derde druk van HAT 5 onder 
die verkorte titel Handwoordeboek van die Afrikaanse Taal. Hiermee saam verskyn daar ook 'n nuwe CD-ROM-weergawe van HAT 5, die e-HAT, met verbeterde spel- en setfoute onder redaksie van Gouws en Luther. (Gouws en Luther 2009: Voorwoord by dié elektroniese uitgawe)

\section{$2.6 \quad$ HAT 6}

In 2012 word nog 'n voltydse leksikograaf, F. Pheiffer, deur HAT se uitgewers, Pearson, aangestel met die oog op "'n omvattende herbewerking en uitbreiding van die HAT" (Luther, Pheiffer en Gouws 2015: vii). So verskyn daar in 2015, 'n halfeeu ná die verskyning van die eerste $H A T$, 'n sesde uitgawe van die Handwoordeboek van die Afrikaanse Taal.

In HAT 6 word daar, selfs meer as in vorige uitgawes, 'n deskriptiewe benadering gevolg. Alhoewel hierdie woordeboek "wat spelling en skryfwyse betref, op enkele uitsonderings na die leiding van die Afrikaanse woordelys en spelreëls" volg, is hierdie standaardwoordeboek se hooffunksie nie voorskrywing nie, maar om "die verskuiwende standaardvariëteit van Afrikaans" te beskryf, aldus Luther, Pheiffer en Gouws (2015: vii-viii, ix). So is daar in sekere gevalle van die Afrikaanse woordelys en spelreëls afgewyk deur die opname van alternatiewe spel- en skryfwyses in HAT 6, selfs al word dit nie in die tiende uitgawe van die Afrikaanse woordelys en spelreëls erken nie (Luther, Pheiffer en Gouws 2015: ix). Soos met die vorige uitgawe is dié deskriptiewe benadering tot 'n groot mate moontlik gemaak deur die elektroniese teksargiewe en woordkorpusse waarop HAT 6 gebaseer is (Luther, Pheiffer en Gouws 2015: viii). In die samestelling van HAT 6 het die redakteurs hulle egter nie alleen op geskrewe standaardtaalbronne beroep nie, maar ook op gesproke en informeler taalgebruik oor die radio, op televisie en in die sosiale media en het hulle ook insae in die werk van verskeie taalberoepslui (bv. joernaliste, teksredakteurs, skrywers en vertalers) gehad (Luther, Pheiffer en Gouws 2015: vii-viii). Die redakteurs het dus weer uit Afrikaans se eie middele geput om dié woordeboek saam te stel en het dit nie meer noodsaaklik geag om op Nederlands te steun nie (sien 2.1).

Dat HAT 6 inderdaad "die grootste hersiening sedert die verskyning van die derde uitgawe" verteenwoordig, blyk reeds uit die makrostruktuur van die woordeboek (Luther, Pheiffer en Gouws 2015: vii). 3228 nuwe lemmas is opgeneem (Luther, Pheiffer en Gouws loc.cit.), onder andere avatar, bed-en-ontbyt-plek, dim sum, feesvoos, Greenpeace, homofobie, internetverslawing, Jozi, kaderontplooiing, kamp (b.nw./bw.), kitsskare, linkerbreinmens, metroman/-seksueel, naanbrood, opkikkertoets, papgeld, reeksverkragter, selfie, selfdood, slimfoon, tjoeftjaf, vetdruk en werklikheidsprogram/-reeks/-televisie. Ten einde 'n volledige beeld te gee "van hoe Afrikaans vandag gebruik word", is daar in HAT 6 se makrostruktuur dan ook, soos in vorige uitgawes, leksikale items uit ander variëteite van Afrikaans ingesluit (Luther, Pheiffer en Gouws 2015: vii-viii). 'n Variëteit van Afrikaans wat besondere aandag in HAT 6 geniet, is Moslemafrikaans; dit is "geloofs- en 
kultuurverwante woorde van Maleise en Arabiese herkoms [...] uit die skryftaal van Moslem-Afrikaanssprekendes" (Taalkommissie 2009: ix). Voorbeelde hiervan is abdas, batja, djannat, ëpoewasa, fadjer, garaam, insja'Allah, kanalla, koenoet, miembar, nabi, oestaad, popgloër, popgloëry, rasoel, salaah en tartiep (vgl. Hugo 2015: 13). Volgens Pheiffer, een van HAT 6 se redakteurs (in Morris 2015), is HAT 6 ook een van die eerste Afrikaanse publikasies wat tot 'n groter mate erkenning gee aan Kaaps deur die opname van leksikale items uit dié variëteit. Dit sluit lemmas soos gattas, kappityt, piemp, sharp, sjarrap, tiep en uitstiek/ytstiek in (Morris 2015). Hugo (2015: 13) is egter van mening dat Kaaps as variëteit nog afgeskeep word in HAT. 'n Groetvorm soos awe wat deesdae al hoe algemener is, ontbreek byvoorbeeld nog. Daar is ook 5365 nuwe betekenisonderskeidings in HAT 6 opgeneem (Luther, Pheiffer en Gouws 2015: vii), byvoorbeeld afpak ("iemand van jou probleme/ellendes vertel"), duidelik (b.nw.) ("goed; reg; mooi; lekker"), gevaarlik ("baie"), tik2 (ww.) ("metamfetamien gebruik") en venster ("rame op 'n rekenaarskerm"). Die groter mate van erkenning wat daar in HAT 6 aan die variëteite van Afrikaans gegee word, spreek van 'n omarming van "eie taalgoedere" van Afrikaans (teenoor die omarming van die "vreemde", Nederlandse, waardeur die eerste uitgawes gekenmerk is).

Aangesien HAT veral op "eietydse taalgebruik" fokus, is daar meer as 3000 ouer woorde en uitdrukkings geskrap (Luther, Pheiffer en Gouws loc.cit.). 'n Mens sou dus verwag dat die Neerlandistiese lemmas in hierdie uitgawe aansienlik verminder is. Wanneer die Neerlandistiese lemmas of lemmas met ' $n$ Neerlandistiese betekenis in 2.1 weer in oënskou geneem word, blyk dit wel die geval te wees. Lemmas wat sedert die vorige uitgawe uit dié lys geskrap is, is agternaam, benieu, benieud, bil, bloesem, blootshoof(s), blootsvoet(s), internaat, invitasie, kneeding, knee(d)baar, onbesuis en twyg. 'n Verdere groep lemmas uit hierdie lys wat wel in HAT 6 behou is, is of vir die eerste keer van leksikografiese etikette voorsien, óf die leksikografiese etikette is uitgebrei - meestal om aan te dui dat hierdie lemmas 'n lae gebruiksfrekwensie het of verouderend/verouderd is:

\begin{tabular}{|c|c|c|}
\hline Lemma & Etiket(te) $H A T 5$ & Etiket(te) $H A T 6$ \\
\hline bloot & ietwat deftig & deftig, verouderend \\
\hline briewebus & - & deftig, verouderend \\
\hline hals & deftig & deftig, verouderend \\
\hline heg & deftig & deftig, verouderend \\
\hline jarig & - & nie alg., verouderend \\
\hline spaarpot & w.g. & w.g., veroud. \\
\hline swyneboel & - & neerh., w.g., veroud. \\
\hline visite (s.nw.) & F., nie alg., deftig & Fr., deftig, w.g. \\
\hline
\end{tabular}

In ander gevalle is ' $n$ kruisverwysing na ' $n$ lemma bygevoeg wat 'n gebruikliker, Afrikaanse vorm verteenwoordig: 


\begin{tabular}{|l|l|l|}
\hline Lemma & Etiket(te) HAT 5 & Etiket(te) HAT 6 \\
\hline briewebesteller & \multicolumn{1}{|c|}{-} & veroud. $\rightarrow$ POSBODE \\
\hline felisiteer/felisitasie & deftig & deftig, veroud. $\rightarrow$ GELUKWENS \\
\hline kameleon & w.g. & soöl., w.g. $\rightarrow$ VERKLEURMANNETJIE \\
\hline moedervlek & veroud. & veroud. $\rightarrow$ GEBOORTEMERK \\
\hline pardon (tw.) & w.g., deftig & deftig, w.g. $\rightarrow$ EKSKUUS \\
\hline steker & \multicolumn{1}{|c|}{-} & elektr. $\rightarrow$ KRAGPROP \\
\hline stopkontak & - & elektr. $\rightarrow$ KRAGPUNT \\
\hline tarwe & w.g. & landb., w.g. $\rightarrow$ KORING \\
\hline
\end{tabular}

Dit geld ook die Neerlandistiese betekenisonderskeiding (1) by giraf:

gi.raf $s . n w$. [ $\sim \mathbf{s} ; \sim$ fie] 1 (soöl.) $\rightarrow$ KAMEELPERD 2 Giraf (astron.) naam van die sterrebeeld Camelopardalis. [...]

Ander lemmas se leksikografiese etikette is onveranderd gelaat sedert die vorige uitgawe:

\begin{tabular}{|l|l|l|}
\hline Lemma & Etiket(te) HAT 5 & Etiket(te) HAT 6 \\
\hline fiets (ww.) & \multicolumn{1}{|c|}{-} & \multicolumn{1}{c|}{-} \\
\hline houthakker & veroud. & veroud. \\
\hline invasie & w.g., deftig & w.g., deftig \\
\hline invektief & w.g., deftig & w.g., deftig \\
\hline kapper & \multicolumn{1}{|c|}{-} & \multicolumn{1}{c|}{-} \\
\hline kloset & veroud. & veroud. \\
\hline kus (s.nw./ww.) & deftig, digt. & deftig, digt. \\
\hline naak & deftig, veroud. & deftig, veroud. \\
\hline origineel & w.g. & w.g. \\
\hline serieus & deftig & deftig \\
\hline sielig & deftig & deftig \\
\hline
\end{tabular}

Uit die hele lys van Neerlandismes, is slegs fiets ("fietsry") en kapper ("haarkapper") steeds ongeëtiketteerd opgeneem. Dié lemmas se gebruikliker, Standaardafrikaanse sinonieme (bo tussen hakies aangedui) vorm wel deel van die semantiese kommentaar. Neerlandismes wat nog in die vorige uitgawe in definiense en voorbeeldmateriaal teenwoordig was, is in HAT 6 óf geskrap, of aangepas. Die kollokasie begane grond en die uitdrukking [iets] duister insien is geskrap. Vergelyk ook in hierdie verband die vervanging van "spreek" met "praat" en "aanbind" met "aantrek" by die lemmas eerlik en skaats onderskeidelik:

eer-lik $b . n w ., b w$. [ e, $\sim$ er, die $\sim$ ste $] 1$ wat die waarheid praat; wat die feite nie verdraai nie: [...]. 
skaats ם s.nw. 1 [ e] een van 'n paar spesiale skoene met aan die onderkant skerp lemme (ysskaatse) of wieletjies (rolskaatse) waarmee 'n mens oor ys of op 'n harde oppervlak kan beweeg: jou skaatse aantrek. [...].

Die poëem "Sy het 'n vet spaarpot" wat voorheen by die lemma spaarpot voorgekom het, is nou uitgebrei tot "Ná jare se geduldige spaar het sy nou sy nou 'n vet spaarpot vir 'n oorsese reis" en die poëem "Daar sielig uitsien" kom steeds by die lemma sielig voor. Ten spyte van laasgenoemde, beskou Hugo (2015: 13) hierdie "suiwering", soos hy dit noem, saam met die opname van nuwe lemmas as die grootste aanwins van HAT 6.

Alhoewel baie ouer woorde uit HAT 6 verwyder is, is hierdie woorde nie heeltemal verlore vir Afrikaanssprekendes nie. Die woorde is behou in ' $\mathrm{n}$ aanlyn "moederwoordeboek", die nuwe HAT Aanlyn op die internet (Luther, Pheiffer en Gouws 2015: vii-viii). Hierdie "lewende" woordeboek, wat saam met die vrystelling van HAT 6 bekendgestel is, is nie 'n blote duplikaat van die gedrukte weergawe nie, maar word sedert sy ontstaan gereeld bygewerk ten einde reg te laat geskied aan Afrikaans as lewende, ontwikkelende taal (Luther, Pheiffer en Gouws 2015: viii). Volgens Luther (2016) word die HAT Aanlyn se inhoud nou omtrent daagliks aangevul en bygewerk.

Wanneer die agterteks in HAT 6, 'n lys met erkennings wat die name van persone bevat uit wie se werk sitate geneem is vir opname in HAT 6, in oënskou geneem word, blyk dié woordeboek se band met die US se Departement Afrikaans en Nederlands. Die lys name sluit ' $n$ hele aantal voormalige en huidige dosente van die US se Departement Afrikaans en Nederlands in, onder andere Willem Anker, Jan F.E. Celliers, Johan Combrink, Meyer de Villiers, Rufus Gouws, J.C. Kannemeyer, Willem Kempen, W.E.G. Louw, D.J. Opperman, F.A. Ponelis, Merwe Scholtz, Lina Spies, Marlene van Niekerk, Dirk van Schalkwyk, Dorothea van Zyl en Louise Viljoen (Luther, Pheiffer en Gouws 2015: 1615-1616).

Hugo (2015: 13) verwys na HAT 6 as "die heel beste en grootste verklarende handwoordeboek in Afrikaans". Desnieteenstaande die aanvanklike steun op Nederlands, het die Handwoordeboek van die Afrikaanse Taal hom oor die verloop van jare losgemaak van Nederlandse invloed en 'n voorloper op die gebied van die Afrikaanse verklarende leksikografie geword.

\section{Nasionale Woordeboek}

\subsection{Kernwoordeboek van Afrikaans}

Slegs twee jaar ná die verskyning van die Verklarende Handwoordeboek van die Afrikaanse Taal, verskyn daar in 1967 die Kernwoordeboek van Afrikaans (voortaan $K v A$ ) onder redakteurskap van J. Smuts, L.C. Eksteen, en die Stellenbosse dosent M. de Villiers. De Villiers was van 1947 tot 1952 senior lektor in Nederlands en Afrikaans aan Stellenbosch, in 1953 word hy aangestel as professor in 
Nederlandse taalwetenskap en Germaanse filologie, en sedert 1975 tot met sy aftrede in 1978 beklee hy die Jan Marais-leerstoel in Afrikaans (Breuer 2016). Met die verskyning van Kernwoordeboek het De Villiers reeds verskeie boeke oor die Afrikaanse en Nederlandse grammatika gepubliseer, onder andere Woordsoorte, werkwoorde en tye (1948), Afrikaans simplified for English-speaking students (1950), Moderne Afrikaanse taalstudie volgens die leerplanne van die junior sekondêre kursus: Afrikaans as eerste taal, Deel II: Standerds VII en VIII (1955), Nederlands vir Suid-Afrika (1956), Nederlands en Afrikaans (1960), Afrikaanse klankleer: Inleiding tot die fonetiek en fonologie (1958, sedert die derde druk in 1965 gewysig en die titel verander na Afrikaanse klankleer: fonetiek, fonologie en woordbou).

Gegewe De Villiers se bemoeienis met Nederlands, sou dit nie verbasend wees indien $K v A$ ook uitvoerige blyke gee van Nederlandse invloed nie. As ' $n$ mens ter wille van vergelykbaarheid die lys Neerlandistiese lemmas in HAT 1 (sien 2.1) met die lemmas in $K v A$ vergelyk, blyk dit dat ses van die Neerlandistiese lemmas wat ongeëtiketteerd in HAT 1 opgeneem is, nie in $K v A$ opgeneem is nie, te wete agternaam ("van"), bil ("boud"), briewebus ("posbus"), kneding (handeling van "knie"), pinda ("grondboontjie") en swyneboel ("vuil huishouding"). 'n Groot aantal is egter, net soos in HAT 1, ongeëtiketteerd opgeneem:

abonneer ("inteken", bv. op 'n koerant), abonnement ("intekening/subskripsie"), bloesem ("bloeisel"), blootshoof(s) ("kaalkop"), blootsvoet(s) ("kaalvoet"), briewebesteller ("posbode/-man"), felisiteer ("gelukwens"), felisitasie ("gelukwensing"), fiets (ww.) ("fietsry"), hals ("nek"), heg ("heining"), houthakker ("houtkapper"), internaat ("kosskool"), kapper ("haarkapper"), kloset ("toilet"), knee(d)baar ("kniebaar"), moedervlek ("geboortemerk/-vlek"), onbesuis ("roekeloos/onstuimig/wild), pardon (tw.) ("ekskuus"), sielig ("droewig"), spaarpot ("spaarbussie"), stopkontak ("muurprop/kragpunt"), toonladder ("toonleer")

Daar is hierbenewens ook Neerlandistiese lemmas in $K v A$ opgeneem wat nie in HAT 1 voorkom nie (vgl. 2.1), byvoorbeeld parasjuut ("valskerm") en pindakaas ("grondboontjiebotter"), of wat eers in HAT 2 opgeneem is, soos belendend ("aangrensend") en stekker ("kragprop"). Anders as in HAT 1 waar slegs drie lemmas met leksikografiese etikette gemerk is (sien 2.1), is daar heelwat van die Neerlandistiese lemmas in $K v A$ wat met die stilistiese etiket ong. (ongewoon) gemerk om daarop te dui dat daar vir die betrokke lemma "'n meer gewone of gebruiklike woord bestaan" (De Villiers, Smuts en Eksteen 1967: Toeligting vir die gebruiker):

benieu ("nuuskierig maak"), benieud ("nuuskierig"), bigotterie ("skynheiligheid"), haag ("heining"), invasie ("inval"), invektief ("skel(d)woord"), invitasie ("uitnodiging"), jarig ("verjaar"), kameleon ("verkleurmannetjie"), kus (s.nw./ ww.) ("soen"), origineel ("oorspronklik"), serieus ("ernstig"), skavuit ("skelm/ skurk"), tarwe ("koring"), twyg ("dun takkie"), visite (s.nw.) ("besoek") 
Laasgenoemde is ook van die stilistiese etiket plegt. (plegtig) voorsien. Soos HAT 1 bevat $K v A$ verder ook Neerlandistiese betekenisonderskeidings:

bloot (blote) b.nw. 1. kaal, onbedek. Met die blote hoof. Die blote lyf. 2. oop, sonder bedekking. Die blote hemel, grond. 3. sonder hulpmiddel. Met die blote oog. 4. eenvoudig. sonder meer, slegs. 'n Blote gissing. Die blote feit.

'steker, 'stekker (-s) s.nw. 1. steekkontak 2. Werktuig waarmee gesteek word; priem.

Die Neerlandistiese betekenisonderskeiding "kaal" word, soos in HAT 1, sonder 'n leksikografiese etiket as eerste betekenisonderskeiding by bloot aangebied. Die indruk word weer geskep dat dit 'n gebruikliker en frekwenter betekenisonderskeiding in Afrikaans verteenwoordig (sien 2.1). By steker/stekker word daar selfs verder gegaan as in HAT 1 deurdat die Neerlandistiese betekenisonderskeiding eerste aangebied word. In KvA is daar eweneens lemmas monosemies hanteer met slegs hulle Neerlandistiese betekenisse:

eventu'eel (-tuele) b.nw. moontlik, gebeurlik; moontlikerwys. Eventuele skade, besware. Afkorting ev. eventuali'teit.

fok (ge-) ww. (ong.) teel. 'fokkery.

gi'raf (-fe, -s) s.nw. dier met 'n ontsaglike lang nek en voorbene, wat in Afrika voorkom.

Alhoewel die Afrikaanse (vulgêre) betekenisonderskeiding van fok nie in $K v A$ opgeneem is nie, is daar wel met 'n leksikografiese etiket aangedui dat die Neerlandistiese betekenis wat wél opgeneem is, ongewoon is in Afrikaans. By die lemma braaf is die meer Afrikaanse betekenisonderskeiding egter opgeneem, hoewel dit nog as anglisisties gemerk is:

braaf (brawe; brawer, -ste) b.nw. (ong.) 1. gehoorsaam, soet 2. deugsaam, fatsoenlik, eerbaar 3. (angl.) dapper.

Die Nederlandse invloed op mikrostrukturele vlak blyk ook uit die teenwoordigheid van Neerlandismes in die definisies en voorbeeldmateriaal. Vergelyk in hierdie verband posbode waar briewebesteller as sinoniemdefinisie aangebied word en die volledige bewerking dan by briewebesteller aangebied word. Die indruk wat hierdeur geskep word, is dat die Neerlandistiese briewebesteller die frekwenter vorm is. ${ }^{6}$

'posbode (-s) s.nw. briewebesteller

'briewebesteller (-s) s.nw. posbeampte wat briewe aflewer.

Dit is egter interessant om daarop te let dat die woord posbode in briewetas se definiens gebruik word en nié briewebesteller nie. Vergelyk ook die gebruik van 
hoof en huid in onderstaande definiense, asook die kollokasie begane grond as deel van begaan se vierde betekenisonderskeiding:

'hoendervleis s.nw. 1. vleis van 'n hoender 2. onwillekeurige sametrekking van bloedvate in die menslike huid en die spiertjies van die hare veroorsaak deur koue, vrees ens.

'stralekrans (-e) s.nw. kring van strale soos gedink en afgebeeld om die hoof van goddelike of heilige wesens.

be'gaan II (-gane) b.nw. 1. bekommerd, besorg. - wees oor die toekoms. 2. met meegevoel vervul. Hy is - oor die armes. 3. ingenome, geesdriftig. - wees met 'n saak. 4 . Weer op begane grond wees, weer op vaste grond. Die begane grond, grondverdieping, natuurlike grondoppervlakte. Begane weë, gebaande paaie. begaandheid (by 1,2,3).

$K v A$ het ook, soos sommige artikelinskrywings in HAT 1, inskrywings wat skynbaar direkte vertalings van inskrywings in die Van Dale Groot Woordenboek der Nederlandse Taal (1961) is. Vergelyk in hierdie verband die Neerlandistiese lemma luk se artikel:

\begin{tabular}{|l|l|}
\hline \multicolumn{1}{|c|}{ KvA (1967) } & \multicolumn{1}{|c|}{ Van Dale 8 (1961) } \\
\hline $\begin{array}{l}\text { luk (ge-) ww. goed uitval, tot stand } \\
\text { kom, geluk, slaag. Dit sal nie - nie. }\end{array}$ & $\begin{array}{l}\text { luk'ken, (lukte, is gelukt), (onoverg.) } 1 . \\
\text { gelukken, goed uitvallen, wel slagen, } \\
\text { tot stand komen: [...] - dat zal niet } \\
\text { lukken, niet gaan, niet mogelijk zijn, } \\
\text { niet toegestaan worden; [...]. }\end{array}$ \\
\hline
\end{tabular}

Vervolgens blyk die invloed van Nederlands ook uit die agterteks "Spelling: enkele basiese beginsels". In die uiteensetting van die ortografiese beginsels van Afrikaans word daar naamlik telkens melding gemaak van die Afrikaanse ortografie se band met Nederlands (De Villiers, Smuts en Eksteen 1967): ${ }^{7}$

Die Afrikaanse spelling (soos die Nederlandse) toon in verskeie gevalle die tekortkominge van die Latynse alfabet vir ons klankweergawe. (640)

In die eerste plek is daar die feit dat ' $n$ vyftig jaar gelede besluit is om ter wille van die historiese en lewende verband met Nederlands nie onnodig van dié taal se spelling af te wyk nie. Die bogenoemde gevalle is 'n voortsetting van die Nederlandse tradisies, en daarby kom nog die gebruik van $y$ en $e i$, en van $f$ en $v$ onderskeidelik. In Nederlands was $y$ en $e i$ op 'n tyd aparte klanke en $f$ en $v$ is dit nou nog ten dele, maar in Afrikaans dui $y$ en ei dieselfde klinker, en $f$ en $v$ dieselfde medeklinker aan, bv. fyn en feit; fort en voor. (640)

' $n$ Tweede besondere spellingverskynsel (ook ' $n$ tradisie in Nederlands) is om $d$ vir die klank $t$ en $b$ vir die klank $p$ te skryf [...]. (640)

In Afrikaans, soos in Nederlands en Duits, word woorde dikwels aanmekaar geskryf [...]. (643) 
Uit die voorafgaande is dit duidelik dat die Nederlandse invloed ook tot $K v A$ deurgedring het. Tog wil dit lyk asof daar in sekere opsigte in $K v A$ probeer is om die Nederlandse invloed te temper deurdat minder Neerlandistiese lemmas opgeneem is of deur meer gebruiksleiding te gee, byvoorbeeld deur die opname van meer leksikografiese etikette.

\subsection{Nasionale Woordeboek}

Slegs vier jaar na die verskyning van $K v A$ verskyn 'n tweede uitgawe van dié woordeboek in 1971, maar nou onder die nuwe titel Nasionale Woordeboek (voortaan NW) met die subtitel Afrikaanse woordverklaring. Oor die verloop van die volgende sestien jaar sou daar nog vyf verdere uitgawes onder dié titel in 1977, 1979, 1981, 1985 en 1987 verskyn. Teen die tyd dat NW 6 in 1985 verskyn, het De Villiers se kollega aan die US se Departement Afrikaans en Nederlands, R.H. Gouws (sien 2.4), hom as mederedakteur by De Villiers, Smuts en Eksteen aangesluit.

Wat die Nederlandse invloed in NW betref, is daar in die sestien jaar nie veel gedoen om die Nederlandse invloed verder te temper nie. Al die Neerlandistiese lemmas wat in $K v A$ opgeneem is, kom steeds met dieselfde leksikografiese etikette in NW 7 voor. Enkele uitsonderings is belendend wat sedert NW 3 met die etiket ong. (ongewoon) gemerk is, en heg wat sedert NW 6 met dié etiket gemerk is. Daar is egter ook enkele gevalle waar daar sprake van ' $n$ terugwaartse stap in die rigting van vernederlandsing blyk te wees. In NW 2 is daar in die agterteks "Spelling: enkele basiese beginsels" selfs meer verwysings na Nederlands bygevoeg (De Villiers, Smuts en Eksteen 1971):

Om dié moeilikheid te bowe te kom, het ons taal-voorouers, die Nederlanders, mettertyd 'n stelsel ontwerp wat ons ook volg t.o.v. die tekort aan vokaalletters. (645)

Afgesien hiervan los die Nederlanders en ons die tekortkominge van die alfabet op deur letterkombinasies wat heeltemal ander klanke verteenwoordig as die afsonderlike letters [...]. (646)

Die lemmas haag, invitasie en kus ("soen") wat in KvA met die etiket ong. gemerk is, onderskeidelik in NW 6 en NW 7 weer ongeëtiketteerd opgeneem. Net so word die Neerlandistiese betekenisonderskeidings by bloot ("kaal, onbedek") en steker/stekker ("steekkontak") in NW 7 steeds eerste aangebied, terwyl eventueel en giraf steeds monosemies hanteer word met slegs hulle Neerlandistiese betekenisse ("moontlik, gebeurlik" en "kameelperd" onderskeidelik). Hoewel fok se meer Afrikaanse betekenis nie bygevoeg is nie, is dié lemma met sy Neerlandistiese betekenis wel uit NW 7 verwyder. Braaf se Afrikaanse betekenisonderskeiding ("dapper") is in NW 7 steeds as anglisisme gemerk. Die Nederlandse invloed in die definisies en voorbeeldmateriaal wat in $K v A$ teenwoordig was in die lemmas posbode, hoendervleis, stralekrans, begaan en luk se artikels is ook 
steeds aanwesig in NW 7. Ondanks die feit dat Neerlandismes skynbaar beter hanteer is in $K v A$ as in $H A T$, is daar nie veel gedoen om die Nederlandse invloed oor die verloop van die sewe uitgawes van $N W$ verder te verminder nie.

In NW 5 is daar wel sprake van 'n meer deskriptiewe benadering deurdat daar in die "Toeligting vir die gebruiker" gemeld word dat, hoewel verskeie betekenisonderskeidings as anglisismes gemerk is, gebruik daarvan nie noodwendig afgekeur word nie (De Villiers, Smuts en Eksteen 1981: Toeligting vir die gebruiker).

\section{Samevatting}

As 'n mens NW 7 met die uitgawe van $H A T$ vergelyk wat gedurende dieselfde tyd in omloop was (dit is HAT 2), vaar NW 7 beter as sy eweknie wat die hantering van Nederlandse invloed betref. Vergelyk in hierdie verband die volgende tabel met Neerlandistiese lemmas in HAT 2 en NW 7 onderskeidelik:

\begin{tabular}{|l|c|c|}
\hline Lemma & HAT 2 (1979) & NW 7 (1987) \\
\hline abonneer (ww.)/abonnement (s.nw.) & $\checkmark$ & $\checkmark$ \\
\hline agternaam & $\checkmark$ & x \\
\hline belendend & $\checkmark$ & ong. \\
\hline benieu & onpers. & ong. \\
\hline benieud & $\checkmark$ & ong. \\
\hline bigotterie & $\checkmark$ & ong. \\
\hline bil & veroud. & x \\
\hline bloesem & $\checkmark$ & $\checkmark$ \\
\hline bloot & $\checkmark$ & $\checkmark$ \\
\hline blootshoof(s) & $\checkmark$ & $\checkmark$ \\
\hline blootsvoet(s) & $\checkmark$ & $\checkmark$ \\
\hline briewebesteller & $\checkmark$ & $\checkmark$ \\
\hline briewebus & $\checkmark$ & x \\
\hline felisiteer (ww.)/felisitasie (s.nw.) & $\checkmark$ & $\checkmark$ \\
\hline fiets (ww.) & $\checkmark$ & $\checkmark$ \\
\hline haag & w.g. & $\checkmark$ \\
\hline hals & $\checkmark$ & $\checkmark$ \\
\hline heg & $\checkmark$ & ong. \\
\hline houthakker & $\checkmark$ & $\checkmark$ \\
\hline internaat & $\checkmark$ w. & $\checkmark$ \\
\hline invasie & $\checkmark$ & ong. \\
\hline invektief & $\checkmark$ & ong. \\
\hline invitasie & $\checkmark$ & $\checkmark$ \\
\hline jarig & & ong. \\
\hline kameleon & $\checkmark$ & \\
\hline
\end{tabular}




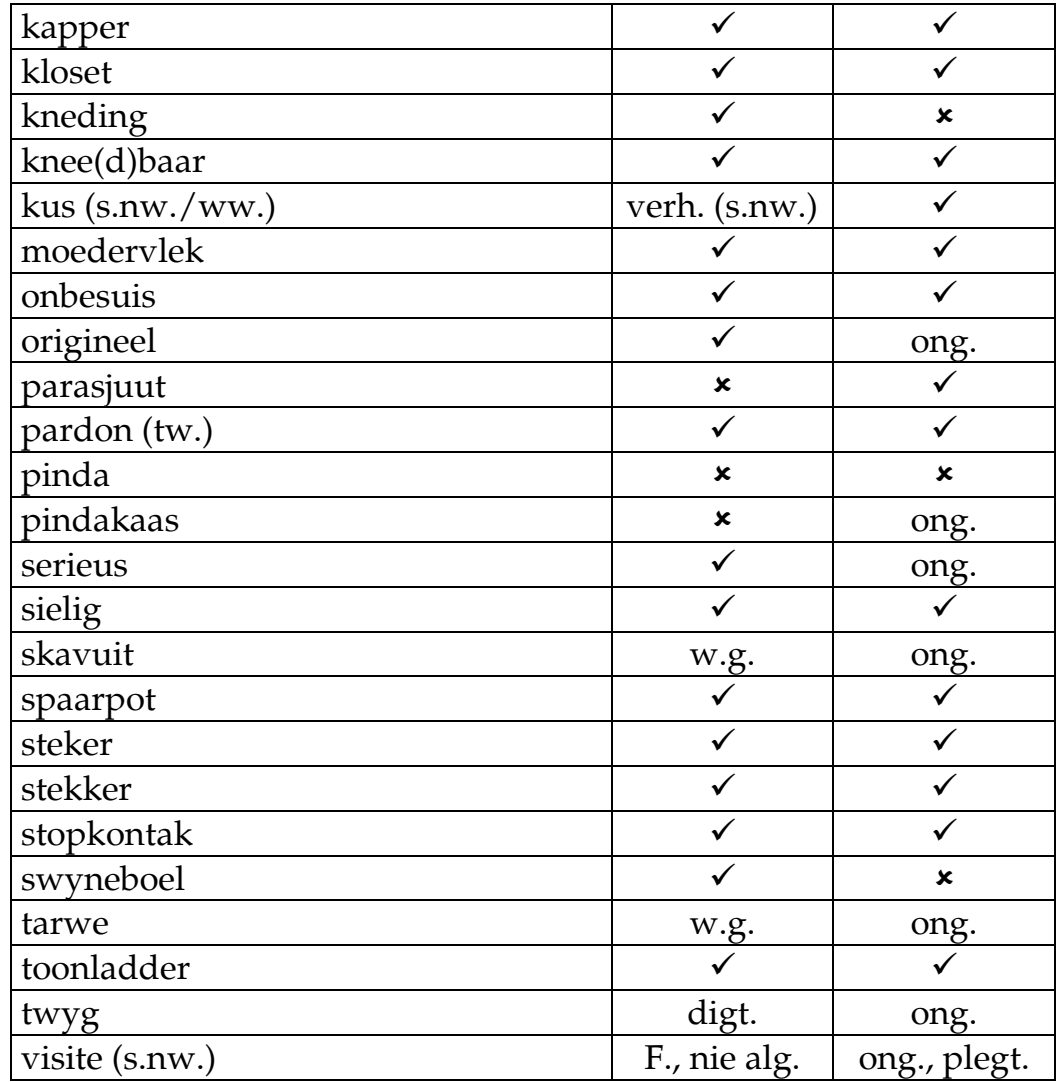

Uit bogenoemde is dit duidelik dat NW 7 meermale Neerlandistiese lemmas óf nie opgeneem het nie, óf van 'n leksikografiese etiket voorsien het waar dit nie in HAT 2 gedoen is nie.

Dit sou sekerlik vergesog wees om NW se enigsins beter hantering van Neerlandismes toe te skryf aan die Stellenbosse dosent, M. de Villiers, se betrokkenheid by dié woordeboek. Dit is myns insiens egter nie onwaarskynlik dat De Villiers se bemoeienis met en kennis van Nederlands (soos bv. weerspieël in sy publikasie van die boek Nederlands en Afrikaans; sien 3.1) aan hom 'n sensitiwiteit ten opsigte van Nederlands se verhouding tot en invloed op Afrikaans gegee het wat uiteindelik oorgespoel het in die samestelling van NW nie. Dit is byvoorbeeld ook interessant om daarop te let dat die Departement AfrikaansNederlands, soos wat die US-departement waarvan De Villiers 'n personeellid was sedert 1952 bekend gestaan het, 8 in 1979 herbenoem is na die Departement Afrikaans en Nederlands. Dit lyk dus asof daar gedurende die tyd wat NW verskyn het 'n groter bewustheid van Afrikaans as selfstandige taal náa Nederlands (en nie ondergeskik aan nie) in die Departement Afrikaans en Nederlands ontstaan het. 
Later, ná die gerekende leksikograaf, R.H. Gouws se toetrede tot die redaksie van $H A T$, het hierdie bewustheid van Afrikaans as selfstandige en lewenskragtige taal oorgespoel na hiérdie standaardwoordeboek. Nadat $N W$ ná die 1980's nie verdere uitgawes beleef het nie, kon HAT put uit die "Goue Eeu van die leksikografie", soos wat Gouws (1989: 24) na die tagtigerjare verwys. Die "ongekende oplewing" in "die teoretiese en praktiese leksikografie" wat hom in dié tydperk afgespeel het (Gouws loc.cit.) en onder andere gekenmerk is deur die publikasie van Gouws se "epogmakende werk" Leksikografie in 1989 (aldus Carstens 1994: 252), het ongetwyfeld sedert die negentigerjare 'n verrykende invloed op HAT gehad, deurdat dié woordeboek hom stadig maar seker van Nederlandse invloed begin losmaak het. Die gevolg is dat die jongste uitgawe van dié woordeboek blyke gee van Afrikaans as 'n selfstandige taal wat nie langer op Nederlands hoef te steun nie.

\section{Slot}

Die Nederlands-Afrikaans-stryd tussen die voorstanders van Nederlands en die voorstanders van Afrikaans wat aan die begin van die twintigste eeu binne die Departement Afrikaans en Nederlands, maar ook in die breër Afrikaanse spraakgebied, posgevat het, het 'n onmiskenbare invloed op die Afrikaanse leksikografie gehad, deurdat daar in die leksikografiese vergestalting van Afrikaans telkens teruggegryp is na Nederlands (vgl. Odendaal 2016 en Odendaal, om te verskyn). Ten spyte daarvan dat die standaardwoordeboeke HAT en NW, waarby personeellede van die Departement betrokke was, heelwat later as hulle vertalende eweknieë verskyn het en hulle dus kon put uit die toenemende bewustheid van die studie van die Afrikaanse taalkunde en ander leksikografiese produkte, kon dié woordeboeke ook nie die Nederlandse invloed waarmee hulle voorgangers belas is (vgl. Odendaal 2016 en Odendaal, om te verskyn), vryspring nie. Soos wat die Departement Afrikaans en Nederlands se naamsverandering in die laat-sewentigs aantoon, het daar egter ' $n$ veranderde ingesteldheid ten opsigte van Nederlands se verhouding tot Afrikaans in die tweede helfte van die vorige eeu ingetree wat uiteindelik ook 'n invloed gehad het op die hantering van Neerlandismes in standaardwoordeboeke. Die gevolg is dat hierdie woordeboeke ' $n$ geleidelike losmaak van Nederlands toon en dat $H A T$ vandag blyke gee van Afrikaans as 'n selfstandige taal wat nie langer op Nederlands hoef te steun nie, maar op eie leksikografiese bene kan staan.

\section{Eindnote}

1. Hierdie woordeboek kan volgens Gouws en Ponelis (1992: 20) nie as 'n standaardwoordeboek beskou word nie, aangesien dit te beperk in omvang is.

2. Die artikel vorm deel van 'n omvattender projek van die Dekaan van die Fakulteit Lettere en Sosiale Wetenskappe van die Universiteit Stellenbosch oor die geskiedenis van die Fakulteit. Dit is die derde artikel in ' $n$ beoogde reeks artikels oor die rol van die Universiteit Stellenbosch se Departement Afrikaans en Nederlands in die ontwikkeling van die Afrikaanse leksiko- 
grafie teen die agtergrond van Afrikaans se stryd teen Nederlands. Die artikel bied nie ' $n$ volledige oorsig oor dié Departement se rol in die ontwikkeling van die Afrikaanse leksikografie nie, maar fokus in die besonder op dosente van die Departement se betrokkenheid by die verklarende standaardwoordeboeke Verklarende Handwoordeboek van die Afrikaanse Taal en Nasionale Woordeboek.

3. Met "Neerlandisties" word in hierdie artikel bedoel "wat die Nederlandse model navolg en in stryd is met die taaleie", terwyl 'n "Neerlandisme" op enige sodanige verskynsel in Afrikaans dui, byvoorbeeld 'n lemma, betekenisonderskeiding, uitdrukking, ensovoorts (vgl. Botha 2014).

4. Die lys is gedeeltelik oorgeneem uit Ponelis (1992: 80-81), Carstens (1995a: 154), Van Houwelingen en Carstens (1998: 5-8), Luther (2010: 677) en Luther (2015) en bygewerk uit HAT 1 (Schoonees et al. 1965). Al die lemmas in die lys is gekontroleer aan die hand van die Dikke Van Dale Online (Den Boon en Hendrickx 2015) en Van Dale Online Hedendaags Nederlands (De Boer 2015). Behalwe invektief wat as formeel en zielig wat as informeel geëtiketteer is in Hedendaags Nederlands, kom al die lemmas of hulle spesifieke betekenisse ongeëtiketteerd in Dikke Van Dale en Hedendaags Nederlands voor, wat daarop dui dat hulle as deel van die Nederlandse standaardtaal beskou word (vgl. Gouws 1989: 147, 201).

5. Die onderskeid tussen hierdie drie etikette word nêrens in die buitetekste belig nie.

6. In HAT 1 kry beide briewebesteller en posbode volledige bewerkings sonder 'n kruisverwysing na die ander lemma.

7. Die verbintenis van die Afrikaanse ortografie met Nederlands is in ooreenstemming met die grondbeginsels van die Afrikaanse spelling soos uiteengesit in die 1964-uitgawe van die Afrikaanse woordelys en spelreëls (vgl. Odendaal 2016: 267). Vergelyk byvoorbeeld die volgende aanhalings uit die 1964-AWS (Taalkommissie 1964):

"Die Afrikaanse spelling wil [...] rekening hou met die spelling wat vandag amptelik in Nederland erken word" (1)

"As ons alleen met die Afrikaanse uitspraak rekening gehou het, sou daar geen rede gewees het om in ons spelling tussen ei en $\mathbf{y}$ en tussen $\mathbf{f}$ en $\mathbf{v}$ te onderskei nie. [...] om kultuurhistoriese redes is besluit om in hierdie geval nie van Nederlands af te wyk nie" (1-2)

8. Dié departement het sedert sy ontstaan in 1922 bekend gestaan as die Departement Nederlands en Afrikaans.

\section{Bronnelys}

\section{Woordeboeke}

Botha, W.F. (Hoofred.). 2014. Elektroniese WAT, A-SKOOI. CD-ROM. Stellenbosch: Buro van die WAT.

De Boer, T. (Hoofred.). 2015. Dikke Van Dale Online 2015. Hedendaags Nederlands. Van Dale Uitgevers. https://www.vandale.nl/zoeken/zoeken.do.

Den Boon, C.A. en R. Hendrickx (Hoofreds.). 2015. Dikke Van Dale Online 2015. Van Dale Uitgevers. https://www.vandale.nl/zoeken/zoeken.do.

De Villiers, M., J. Smuts en L.C. Eksteen. 1967. Kernwoordeboek van Afrikaans. Kaapstad: Nasou.

De Villiers, M., J. Smuts en L.C. Eksteen. 1971. Nasionale Woordeboek. Tweede uitgawe. Kaapstad: Nasou. 
De Villiers, M., J. Smuts en L.C. Eksteen. 1977. Nasionale Woordeboek. Derde, hersiene en uitgebreide uitgawe. Kaapstad: Nasou.

De Villiers, M., J. Smuts en L.C. Eksteen. 1979. Nasionale Woordeboek. Vierde, hersiene en uitgebreide uitgawe. Kaapstad: Nasou.

De Villiers, M., J. Smuts en L.C. Eksteen. 1981. Nasionale Woordeboek. Vyfde, hersiene en uitgebreide uitgawe. Kaapstad: Nasou.

De Villiers, M., J. Smuts, L.C. Eksteen en R.H. Gouws. 1985. Nasionale Woordeboek. Sesde, hersiene en uitgebreide uitgawe. Kaapstad: Nasou.

De Villiers, M., J. Smuts, L.C. Eksteen en R.H. Gouws. 1987. Nasionale Woordeboek. Sewende, hersiene uitgawe. Kaapstad: Nasou.

Gouws, R. en J. Luther. 2009. e-HAT 2009. CD-ROM. Kaapstad: Pearson Education SA.

Kruyskamp, C. 1961. Van Dale Groot Woordenboek der Nederlandse Taal. Agste, omvattend herbewerkte en vermeerderde druk. 's-Gravenhage: Martinus Nijhoff.

Luther, J., F. Pheiffer en R.H. Gouws (Reds.). 20156. Handwoordeboek van die Afrikaanse Taal. Kaapstad: Pearson.

Odendal, F.F. (Hoofred.). 19792. Verklarende Handwoordeboek van die Afrikaanse Taal. Johannesburg/ Kaapstad: Perskor.

Odendal, F.F. (Hoofred.). 1994³. Verklarende Handwoordeboek van die Afrikaanse Taal. Midrand: Perskor.

Odendal, F.F. en R.H. Gouws (Reds.). 20004. Verklarende Handwoordeboek van die Afrikaanse Taal. Midrand: Perskor.

Odendal, F.F. en R.H. Gouws (Reds.). 20055. Verklarende Handwoordeboek van die Afrikaanse Taal. Kaapstad: Pearson Education South Africa.

Schoonees, P.C., C.J. Swanepoel, S.J. du Toit en C.M. Booysen. 1965. Verklarende Handwoordeboek van die Afrikaanse Taal. Klerksdorp/Johannesburg/Pretoria: Voortrekkerpers.

\section{Ander bronne}

Beyer, H.L. 2005. Standaardwoordeboek en kernwoordeboek: 'n Vergelykende evaluering. Lexikos 15: $1-37$.

Botha, W. 2005. Nuwe HAT modern, leier in klas. Die Burger, 31 Oktober 2005: 15.

Botha, W., P. Mavoungou en D. Nkomo (Reds.). 2013. Festschrift: Rufus H. Gouws. Stellenbosch: SUN PReSS.

Breuer, R. 2016. Meyer de Villiers. Stellenbosch Writers. http://www.stellenboschwriters.com/ devilliersme.html (16 Mei 2016).

Carstens, A. 1994. Verklarende Afrikaanse Woordeboek as spieël van normverplasing. Lexikos 4: 249-281.

Carstens, A. 1995a. 'n Kritiese beskouing van HAT3. Lexikos 5: 138-165.

Carstens, A. 1995b. Ideologiese normverplasings en die Afrikaanse handwoordeboek van die negentigerjare. Literator 16(1): 13-30.

Gouws, R.H. 1989. Leksikografie. Pretoria/Kaapstad: Academica.

Gouws, R.H. 1995. Ou wyn in nuwe sakke: 'n Metaleksikografiese herwaardering van enkele komponente in Mansvelt se Idioticon. Bosman, N. (Red.). 1995. ' $n$ Man van Woorde: 42-58. Pretoria: J.L. van Schaik.

Gouws, R.H. 2003. Oor patriotte en ander leksikografiese vernuwers. Botha, W. (Red.). 2003. 'n Man wat beur: 71-85. Stellenbosch: Buro van die WAT. 
Gouws, R.H. en F.A. Ponelis. 1992. Issues in the Development of Afrikaans Lexicography. SuidAfrikaanse Tydskrif vir Taalkunde. Supplement 12: 1-44.

Gouws, R.H. en D.J. Prinsloo. 2005. Principles and Practice of South African Lexicography. Stellenbosch: SUN PReSS.

Hugo, D. 2015. Daar is nog baie skop in dié 'antie'. Rapport Weekliks, 9 Augustus 2015: 13. http:// www.netwerk24.com/Vermaak/Boeke/Daar-is-nog-baie-skop-in-die-antie-20150809 (30 April 2016).

Le Roux, T.H., D.F. Malherbe en J.J. Smith. 1917. Afrikaanse woordelijs en spelreëls. Bloemfontein: Het Volksblad-drukkerij.

Luther, J. 2010. A Language on the Back Foot. The Afrikaans Lexicographer's Dilemma. EURALEX. Euralex 2010 Proceedings. http://www.euralex.org/elx_proceedings/Euralex2010/054_Euralex_ 2010_3_LUTHER_A\%20language\%20on\%20the\%20back\%20foot_The\%20Afrikaans\%20lexico graphers\%20dilemma.pdf (2 Junie 2016).

Luther, J. 2015. HAT 50 jaar. Lesing gelewer by die African Association for Lexicography (AFRILEX) se 20ste Internasionale Konferensie, 6-8 Julie 2015, Universiteit van KwaZulu-Natal, Durban, Suid-Afrika.

Luther, J. 2016. [Persoonlike korrespondensie per e-pos]. 12 Mei.

Morris, M. 2015. Kyk hoe lyk Afrikaans nou. Sunday Argus, 2 Augustus 2015: 17. http://www.iol. co.za/news/kyk-hoe-lyk-afrikaans-nou-1894635 (7 Mei 2016).

Nederlandse Taalunie. 2015. Taalunieversum. Taaladvies. Gelijkvloers/begane grond/ beneden-verdieping. http://taaladvies.net/taal/advies/vraag/1021/gelijkvloers_begane_ grond_benedenverdieping/ (2 Mei 2016).

Odendaal, G. 2016. Die rol van die US se Departement Afrikaans en Nederlands in die ontwikkeling van die Afrikaanse leksikografie: Die Nederlands-Afrikaans-stryd gedurende die aanvangsjare. Tydskrif vir Geesteswetenskappe 56(1): 257-276.

Odendaal, G. Om te verskyn. Die rol van die US se Departement Afrikaans en Nederlands in die ontwikkeling van die Afrikaanse leksikografie onder Nederlandse invloed: Woordeboek van die Afrikaanse Taal.

Odendal, F.F. 2006. HAT veertig jaar — 'n persoonlike oorsig. Lexikos 16: 280-289.

Ponelis, F.A. 1992. Standaardafrikaans in oorgang. Webb, V.N. (Red.). 1992. Afrikaans ná apartheid: 69-89. Pretoria: J.L. van Schaik.

Schoonheim, F. 1998. Een studie naar aspecten van de invloed van de Nederlandse lexicografie op Afrikaanse woordenboeken. Ongepubliseerde M.A.-verhandeling. Stellenbosch: Universiteit van Stellenbosch.

Snijman, F.J. (Hoofred.). 1964. U woorde, u woordeboek. Stellenbosch: Raad van Beheer oor Die Afrikaanse Woordeboek.

Snijman, F.J. 1975. U woorde, u woordeboek. Lantern 25(1): 2-9.

Taalkommissie (van die Suid-Afrikaanse Akademie vir Wetenskap en Kuns). 1964. Afrikaanse woordelys en spelreëls. Sewende, verbeterde uitgawe. Kaapstad: Tafelberg.

Taalkommissie (van die Suid-Afrikaanse Akademie vir Wetenskap en Kuns). 2009. Afrikaanse woordelys en spelreëls. Tiende, verbeterde en omvattend herbewerkte uitgawe. Kaapstad: Pharos Woordeboeke.

Van Houwelingen, F. en A. Carstens. 1998. "Nederlandismes" in HAT33. Literator 19(2): 1-12. 